\title{
Advocating for children: Charles Dickens
}

\section{Richard B. Gunderman ${ }^{1}$}

Received: 4 December 2019 / Revised: 4 December 2019 / Accepted: 20 December 2019 / Published online: 4 January 2020

(C) Springer-Verlag GmbH Germany, part of Springer Nature 2020

One of the most effective advocates for children was also one of the greatest writers in the history of the English language: Charles Dickens. Wildly popular in his own day and now recognized as a literary master, Dickens probably did more than any other author to raise public awareness of the plight of children, laying the groundwork for a variety of social reforms. Physicians seeking an understanding of what poverty and exploitation look like from a child's point of view could hardly find richer sources of insight than such Dickens novels as Oliver Twist, David Copperfield, Bleak House and Little Dorrit.

\section{Dickens}

Charles Dickens was born in 1812 in Portsmouth, England, the second of eight children [1]. His father was a naval clerk who fell into debt and was forced into debtors' prison when Dickens was 12. The younger Dickens had to leave school to work 10-h shifts in a shoe polish factory, which left a deep impression on him of the lot of poor children. As a youth, he also gained an appreciation of how bereft a young person who lacks mentorship and compassion can feel, writing "I had no advice, no counsel, no encouragement, no consolation, no assistance, no support of any kind, from anyone" [1].

At age 15, Dickens got a job in a law firm, and he used his wages to attend theater productions. He then became a court reporter and developed his ability to caricature the people he saw before the bench, further enhancing his understanding of the poor. In his $20 \mathrm{~s}$, he published early works such as Sketches

Richard B. Gunderman

rbgunder@iu.edu

1 Department of Radiology, Riley Hospital for Children, Indiana University, 702 North Barnhill Drive, Room 1053, Indianapolis, IN 46202, USA by Boz and The Pickwick Papers. At 24, he married Catherine Hogarth, who eventually bore them 10 children. Soon Dickens was publishing serialized versions of his novels, including Oliver Twist, Nicholas Nickleby and The Old Curiosity Shop.

Dickens visited the United States twice, once in 1842 and again in 1867. When Dickens died of a stroke at age 58 in 1870, he was laid to rest in Poets' Corner at Westminster Abbey. He had created some of literature's most recognizable characters, and his works have not gone out of print. He attracted the admiration of some of the world's greatest novelists, including Leo Tolstoy and Fyodor Dostoevsky [2], and Vincent Van Gogh credited Dickens' A Christmas Carol with preventing the artist from committing suicide [3]. Dickens also shapes our language through neologisms such as "Dickensian," "Scrooge" and "Humbug!"

\section{Oliver Twist}

Dickens' second novel, Oliver Twist [4], published between 1837 and 1839 , tells the story of a young orphan who is born in a workhouse and sold into apprenticeship with an undertaker. After escaping, he falls under the influence of a band of thieves and their leader, Fagin. He also meets a young girl, Nancy - the lone figure who feels any sympathy for him who is locked in an abusive relationship with the robber Bill Sikes. Dickens is relentless in critiquing child labor, both in legal and criminal enterprises, and exposing the hypocrisy of a society that allows children to live on the streets.

In a passage from Chapter 2 that drips with satire, Dickens describes the workhouse:

So they established the rule that all poor people should have the alternative (for they would compel nobody, not they) of being starved by a gradual process in the house, or by a quick one out of it. ... They made a great many 
other wise and humane regulations ... kindly undertook to divorce poor married people, instead of compelling a man to support his family, as they had theretofore done, and took his family away from him!

Dickens was reacting to a recent amendment to Britain's poor laws that restricted assistance to those who took up residence in official workhouses, where wives and husbands were separated. The intent may have been to punish idleness and strengthen the association between work and virtue, but the practical effect was to pull families apart, ensure that children were treated as units of production, and institutionalize malnutrition, infectious disease, and lack of education. Dickens' stinging account is rendered even more poignant by the fact that he had personally endured much of what he decried.

\section{David Copperfield}

Dickens' eighth novel, David Copperfield [5], was published between 1849 and 1850 . This novel was his most autobiographical and his favorite. It tells the story of a boy born 6 months after his father's death, who is raised by his mother and housekeeper. When David's mother marries a cruel man, the boy is sent to a boarding school presided over by a sadistic master. He makes friends, but when his mother dies, he is sent to London to work in his stepfather's warehouse. He runs away and lives with a family, the Wickfields, and falls in love with their daughter, Agnes. Eventually, he moves to Australia, becomes a writer, and marries her.

In Chapter 7, Dickens describes a cruel schoolmaster, Mr. Creakle, who practically delights in inflicting pain on his students:

I should think there never can have been a man who enjoyed his profession more than Mr. Creakle did. He had a delight in cutting at the boys, which was like the satisfaction of a craving appetite. I am confident that he couldn't resist a chubby boy, especially; that there was a fascination in such a subject, which made him restless in his mind, until he had scored and marked him for the day. I was chubby myself and ought to know.

The novel is filled with the abuse of the weak by the powerful. Children, especially orphans, women and the mentally disabled repeatedly suffer at the hands of those who can get away with mistreating them. Again, debtors' prisons and child labor come in for harsh criticism. The only solution, Dickens seems to suggest, is for the weak to find allies among the powerful or perhaps more to the point, for the powerful to reach out and support and defend the vulnerable. Mere innocence and virtue are not enough - power must be aligned with virtue if those in need are to survive.

\section{Bleak House}

Bleak House [6] was published between 1852 and 1853. It contains numerous plots and a gallery of characters too complex to summarize. In broad terms, however, it represents a satire of the British judicial system, couched in disputes over inheritance, a challenged will, and large amounts of money and land. In a variety of ways, the court case affects each of the characters, suggesting that the obsession with rules and regulations, property and money, and prestige and power can distract us from the human beings who should rank first in our concern.

Consider, for example, Dickens' indictment of British law, which forsakes justice and the protection of the vulnerable for self-interest:

The one great principle of the English law is, to make business for itself. There is no other principle distinctly, certainly, and consistently maintained through all its narrow turnings. Viewed by this light it becomes a coherent scheme, and not the monstrous maze the laity are apt to think it. Let them but once clearly perceive that its grand principle is to make business for itself at their expense, and surely they will cease to grumble.

If children suffer, Dickens suggests, it is often because we forget that the law is not always just, marriage is not always marked by love, and philanthropy is not always helpful. Courts and lawyers may begin to think more about their own welfare than those they are meant to represent. Spouses may become so obsessed with matters outside marriage, such as a legal case, that they forget to care for each other. The most dedicated do-gooders sometimes become so preoccupied with their far-flung projects that they forget those closest to them.

\section{Little Dorrit}

Published between 1855 and 1857, Dickens' 11th novel, Little Dorrit [7], tells the story of a girl, Amy Dorrit, who is raised in a debtors' prison, where she spends much of her life. Though raised under miserable circumstances, she develops into a capable and caring person. She works as a seamstress for a family whose son, Arthur, falls in love with her. With time, the Dorrits prosper and Arthur falls into debt. Later, it is revealed that Arthur's mother has been cheating him and the Dorrits, and Arthur and Little Dorrit gain freedom to marry.

Dickens caricatures the tendency to place a value on human beings, particularly children, in this quote by Arthur, who is commodified even by his own parents: "I am the only child of parents who weighed, measured, and priced everything: for whom what could not be weighed, measured and priced had no existence." 
Such people measure everything, including their own children, by the profit they can derive from them. Justice, mercy, love - they cannot be weighed, measured, or priced, and from such a point of view, they are therefore worthless. This sentiment is reminiscent of Oscar Wilde's description of a cynic as someone who knows the price of everything but the worth of nothing. How can children thrive in a world where wealth, prestige and appearance have completely blotted out human goodness? Where bureaucracy predominates, the human capacity to love is almost certain to languish.

\section{Dickens and child welfare}

Dickens' novels stand at the head of a long line of great English literary works that called attention to the neglect and abuse of children [8]. In Charlotte Bronte's Jane Eyre (1847), an orphan is mistreated by a headmaster and made to suffer for being one of the "charity children." Harriet Beecher Stowe's Oldtown Folks (1869) tells of two sets of orphans who are abused in the name of discipline. In Baa, Black Sheep (1888), Rudyard Kipling tells the tale of his alter ego, Punch, whose self-respect is destroyed by a malignant woman who beats him at home for having been beaten at school.

Dickens' most important contribution in the area of child welfare was to raise public consciousness of the plight of children, but his writings also bore practical fruit. For example, the first children's hospital in the United Kingdom, Great Ormond Street, was founded in 1852. It is the same institution to which J. M. Barrie bequeathed the copyright to Peter Pan [9]. Not only had Dickens' writings helped to generate public support that led to the hospital's founding, but he also integrated the children's hospital into his story A House to Let (1858), and his last novel, Our Mutual Friend (1864-1865).

The educational worth of Dickens' works is undiminished by time, and it has even been suggested that works such as Oliver Twist could serve today as a textbook of child abuse [10]. The novel enumerates the risk factors of abuse, including alcohol, domestic violence and mental illness. It catalogs in unforgettable detail a variety of forms abuse can take: institutional, emotional, physical and sexual. And it outlines numerous sequelae of abuse, including physical and mental ailments and disabilities, poor self-esteem, and general vulnerability to exploitation.

Dickens' contributions to child welfare are perhaps nowhere better captured than in these words of British actor Simon Callow, who wrote:
The reason I love [Dickens] so deeply is that, having experienced the lower depths, he never ceased, till the day he died, to commit himself, both in his work and in his life, to trying to right the wrongs inflicted by society, above all, by giving the dispossessed a voice. From the moment he started to write, he spoke for the people, and the people loved him for it, as do I [11].

As they reverberate down through the centuries, Dickens' works continue to serve as a clarion call to all physicians to advocate for the voiceless, and especially children. Although giving money, serving on committees, working for private and public policy and service groups, and even serving in public office can each serve children's interests, one of the most important means remains the form of advocacy favored by Dickens himself: sharing the stories of children as effectively as possible. When it comes to advocacy, there is simply no substitute for compassion grounded in human understanding.

\section{Compliance with ethical standards}

Conflicts of interest None

\section{References}

1. Tomalin C (2012) Charles Dickens: a life. Penguin Books, New York

2. Nabokov V (1981) Nabokov on Dostoyevsky. The New York Times, p 35

3. Davies L (2019) 'The love of books is holy': how Van Gogh lost himself in Shakespeare and Dickens. The Telegraph. https://www. telegraph.co.uk/art/artists/love-books-holy-van-gogh-lostshakespeare-dickens/. Accessed 17 Dec 2019

4. Dickens C (2003) Oliver Twist. Penguin Classics, New York

5. Dickens C (2005) David Copperfield. Penguin Classics, New York

6. Dickens C (2011) Bleak House. Signet Classics, New York

7. Dickens C (1992) Little Dorrit. Everyman's Library, New York

8. Bremner R (1995) Child welfare in fiction and fact. Child Welfare 74:19-31

9. Boehm K (2009) "A place for more than bodily sickness": Charles Dickens, the social mission of 19th-century pediatrics, and the Great Ormand Street Hospital for Sick Children. Victorian Rev 35:153-174

10. Brennan PO (2001) Oliver Twist, textbook of child abuse. Arch Dis Child 85:504-505

11. Callow S (2012) My hero: Charles Dickens. The Guardian. https:// www.theguardian.com/books/2012/feb/04/my-hero-charlesdickens-callow. Accessed 17 Dec 2019

Publisher's note Springer Nature remains neutral with regard to jurisdictional claims in published maps and institutional affiliations. 